\title{
Analysis of the Graduate Studies in Different Disciplines Prepared for Music Education in Turkey
}

\section{Zuluf Oztutgan ${ }^{\rtimes}$ Kaan Oztutgan ${ }^{2}$}

${ }^{1,2}$ Osmaniye Korkut Ata University, Faculty of Architecture, Design and Fine Arts, Department of Music, Osmaniye, Turkey.

Email:zulufarslanoglu@yahoo.com Tel: +905530738055

sEmail. kaanort@hotmail.com Tel:+905334910174

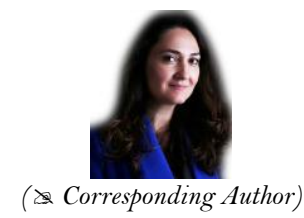

Abstract

This qualitative research is a descriptive study aiming to analyze the graduate studies in different disciplines prepared for music evaluation and to reveal the current situation in TurkeyThe sample of the study involves 25 graduate theses in different disciplines which are in the database of the National Thesis Center and defended in line with music education field. These theses were examined with content analysis and 10 criteria as follows: thesis type, its university, recearcher's gender, publication year, title of advisor, its institute, its department, research area, research model and research class. The findings were interpreted in tables by calculating the frequency and percentage. The findings reveal that $76 \%$ of the examined theses in the scope of this study are master's (MA), $20 \%$ doctorate $(\mathrm{PhD})$ and $4 \%$ specialty in medicine theses. Most of the MA theses were prepared in Hacettepe University, and most of the $\mathrm{PhD}$ theses were prepared in Ankara University and the specialty in medicine thesis was completed in Gaziosmanpaşa University. In addition, most of these theses were written by female researchers and the number of theses in different disciplines prepapred for music education in Turkey is not numerous. Music education and preschool education were associated, and most of the $\mathrm{PhD}$ theses had equal distribution in the fields of Education Policies, Preschool Education, Mathematics Education, Empathic Skills and Sociology. Lastly, it was revealed that most of the theses were prepared based on descriptive model and quantitative approach.

Keywords: Music, Education, Music education, Graduate studies, Interdisciplinary studies, Qualitative research.

Citation | Zuluf Oztutgan; Kaan Oztutgan (2020). Analysis of the Graduate Studies in Different Disciplines Prepared for Music Education in Turkey. Asian Journal of Education and Training, 6(4): 651-657.

History:

Received: 28 September 2020

Revised: 21 October 2020

Accepted: 5 November 2020

Published: 18 November 2020

Licensed: This work is licensed under a Creative Commons Attribution 3.0 License $(\mathrm{cc}) \mathbf{E r}$

Publisher: Asian Online Journal Publishing Group
Acknowledgement: Both authors contributed to the conception and design of the study.

Funding: This study received no specific financial support

Competing Interests: The authors declare that they have no conflict of interests.

Transparency: The authors confirm that the manuscript is an honest, accurate, and transparent account of the study was reported; that no vital features of the study have been omitted; and that any discrepancies from the study as planned have been explained.

Ethical: This study follows all ethical practices during writing.

\section{Contents}

1. Introduction ...s.

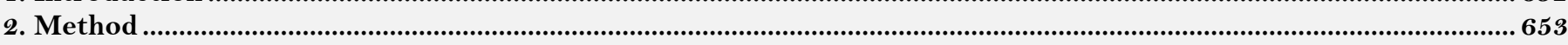

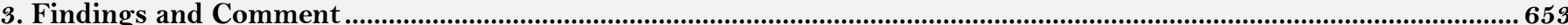

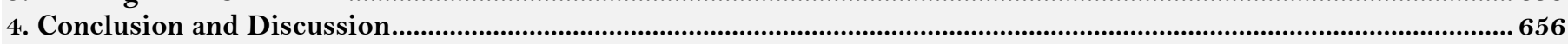

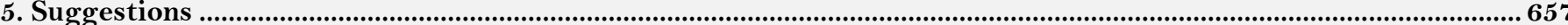

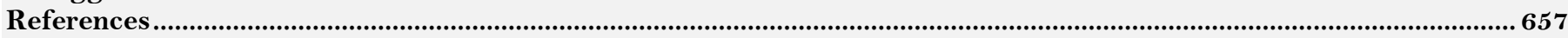




\section{Contribution of this paper to the literature}

This study aimed to contribute to the literature by the determination of graduate studies prepared in different disciplines for music education.

\section{Introduction}

Almost every researcher who has a scientific point of view wants to have detailed information about the resources conducted in her/his field. The need to identify issues that have never been studied before or studies that have been studied but have deficiencies as well as generating new ideas by taking inspiration from the studies conducted in the relevant field may be considered among this request. Considering the diversity of resources and the difficulties in accessing them, it can be said that analyzing and describing the related literature is a very demanding and difficult task. Thus, researchers prefer to limit their studies instead of covering the entire literature. This situation is also valid for literature in music education.

There are a large number of studies describing music education literature in Turkey. Some of them are about the articles about music as in Ece (2007) study, "Music Related Articles Published in Scientific Journals (Bibliography)(2000-2006)" and some are about papers as in Ercan and Yıldırım (2016) study, "Analysis of Music Conferences Held in Turkey: MUZED Silk Road Conferences Sample" In addition, Varış (2012) "The analysis of postgraduate dissertations on viola written in Turkey" and Alyörük (2016) " Graduate Thesis in Field of Guitar Performed in Turkey: A Bibliography Study" are article examples that are about graduate studies.

Descriptive studies that have been or will be made for any resources (articles, books, papers, thesis, etc.) that make up the literature will undoubtedly contribute to the researchers and the field. However, it is possible to say that it is the graduate studies that constitute the basis of the literature, considering that they are prepared in a long process involving the use of university facilities (research center, laboratory etc.) and they are shaped at least by one advisor competent in the field and defended before a competent jury. That's why, research on graduate studies are of great importance in studies that aim to describe and examine the literature.

It is seen that in their studies on literature evaluation and analysis, researchers generally focus on graduate studies conducted in the relevant/related department(s). Considering that a large part of the literature consists of graduate studies in the relevant department, this situation is usual but it should be kept in mind that graduate studies prepared in departments of other disciplines which are dealt with from a different dimension and perspective can make a great contribution to the field. For this reason, it is seen that such studies, which are considered as "interdisciplinary", are increasingly included. As a matter of fact, Ece and Ceşit (2011) that most of the interdisciplinary research in the field of music has been conducted in the recent history and interdisciplinary studies have increased as we come today, supports this situation. Therefore, graduate studies prepared in different disciplines to describe the music education literature should also be investigated.

\subsection{Statement of the Problem}

This study's statement of the problem is "What is the current status of graduate studies in different disciplines prepared for music education in Turkey?"

\subsection{Sub-Problems}

This study tried to find answers to the sub-problems given below.

1. How is the distribution of graduate studies in different disciplines prepared for music education in Turkey according to their types?

2. How is the distribution of graduate studies in different disciplines prepared for music education in Turkey according to the universities they were prepared for?

3. How is the distribution of graduate studies in different disciplines prepared for music education in Turkey according to the gender of researchers?

4. How is the distribution of graduate studies in different disciplines prepared for music education in Turkey according to the publication year?

5. How is the distribution of graduate studies in different disciplines prepared for music education in Turkey according to the title of advisor?

6. How is the distribution of graduate studies in different disciplines prepared for music education in Turkey according to the institutes?

7. How is the distribution of graduate studies in different disciplines prepared for music education in Turkey according to the department?

8. How is the distribution of graduate studies in different disciplines prepared for music education in Turkey according to the research area?

9. How is the distribution of graduate studies in different disciplines prepared for music education in Turkey according to the researh models?

10. How is the distribution of graduate studies in different disciplines prepared for music education in Turkey according to the research class?

\subsection{Aim and Significance of the Study}

This study which is considered to be important in terms of evaluating a different dimension of the music education literature aims to analyze graduate theses in different disciplines prepared for music education in accordance with defined criteria and to reveal the current situation in Turkey. 


\section{Method}

\subsection{Research Model} used.

This qualitative research is a descriptive study in which literature review and document analysis techniques are

\subsection{Population and Sample}

The population of this research consists of graduate studies in different disciplines prepared for music education in Turkey. The sample of the study, on the other hand, consists of 25 graduate studies in different disciplines, which are in the database of the National Thesis Center and conducted in the field of music education.

In order to determine the sample, the database was accessed through the official website of the National Thesis Center (2020) and a search was made by typing "music education" in the search term section. As a result of the search, 459 postgraduate theses with "music education" in the title were determined as of 04.09.2020.

Out of the 459 theses, in order to determine non-area ones, the criteria of department, art major, thesis subject and advisor were examined. In accordance with the purpose of the research, theses conducted in the departments and art majors directly related to music such as the department of music education, music art major, music education art major and Turkish Music art major were not included in this study. Among theses where the department and art majors were not determined, theses directly related to music education were excluded by examining thesis subject, content and advisor's research area. With this method, the number of graduate theses in different disciplines prepared for music education was determined to be 25 .

\subsection{Data Collection}

Yıldırım and Şimşek (2013) state that document analysis can be used alone as a data collection method in qualitative research, as well as in combination with other data collection methods. In this study, literature review and document analysis method were used in data collection.

\subsection{Data Analysis}

In the analysis phase of the research, first of all, similar studies in literature review were examined and the categories to be analyzed were determined based on these studies.

Within this context, 10 criteria were determined, namely the type of thesis, the university where it was prepared, the researcher's gender, the publication year, the title of the advisor, the institute it was prepared for, the department / program it was prepared in, the field of study, the research model and the research class. After the criteria were determined, the theses were analyzed using the content analysis method. The data were interpreted in tables by calculating the frequency and percentage.

\section{Findings and Comment}

In this study, graduate studies in different disciplines prepared for music education in Turkey have been evaluated in accordance with the determined criteria. The frequency and percentage values of the categories made according to the Thesis Type criteria are given in Table 1.

\begin{tabular}{l|c|c} 
Table-1. Distribution of graduate theses in different disciplines prepared for music education in turkey regarding their types. \\
\hline Thesis type & $\mathbf{f}$ & $\mathbf{\%}$ \\
\hline Masters of Degree (MA) & 19 & 76 \\
\hline Philosophy of Doctorate (PhD) & 5 & 20 \\
\hline Specialty in medicine & 1 & 4 \\
\hline Total & 25 & 100 \\
\hline
\end{tabular}

As seen in Table $1,76 \%$ of the theses examined within the scope of this study consist of MA, $20 \% \mathrm{PhD}$ and $4 \%$ specialty in medicine.

\begin{tabular}{|c|c|c|c|c|c|c|}
\hline \multirow[t]{2}{*}{ University } & \multicolumn{2}{|c|}{ MA } & \multicolumn{2}{|c|}{ PhD } & \multicolumn{2}{|c|}{ Specialty in Medicine } \\
\hline & f & $\%$ & f & $\%$ & f & $\%$ \\
\hline Ankara University & 1 & 5,263 & 3 & 60 & - & - \\
\hline Hacettepe University & 3 & 15,789 & - & - & - & - \\
\hline Anadolu University & - & - & 1 & 20 & - & - \\
\hline Gaziosmanpaşa University & - & - & - & - & 1 & 100 \\
\hline İstanbul Aydın University & 1 & 5,263 & - & - & - & - \\
\hline Gazi University & 2 & 10,526 & 1 & 20 & - & - \\
\hline Uludağ University & 2 & 10,526 & - & - & - & - \\
\hline Çanakkale Onsekiz Mart University & 1 & 5,263 & - & - & - & - \\
\hline Atatürk University & 2 & 10,526 & - & - & - & - \\
\hline Ege University & 2 & 10,526 & - & - & - & - \\
\hline Bolu Abant İzzet Baysal University & 2 & 10,526 & - & - & - & - \\
\hline Marmara University & 1 & 5,263 & - & - & - & - \\
\hline Boğaziçi University & 1 & 5,263 & - & - & - & - \\
\hline İstanbul University & 1 & 5,263 & - & - & - & - \\
\hline Total & 19 & 100 & 5 & 100 & 1 & 100 \\
\hline
\end{tabular}

As seen in Table 2, the percentage of the theses defended regarding the universities is respectively: 15,789\% for Hacettepe University; 10,526 for Atatürk University, Ege University, Bolu Abant İzzet Baysal University, Gazi University and Uludağ University, and 5,263\% for Ankara University, Marmara University, Boğaziçi University, 
İstanbul University, İstanbul Aydın University and Çanakkale Onsekiz Mart University. Of these theses, 60\% was defended in Ankara University and $20 \%$ in Anadolu and Gazi Universities. The study in speciality in medicine was completed in Gaziosmanpaşa University.

Table-3. Distribution of graduate theses in different disciplines prepared for music education in turkey regarding the researcher's gender.

\begin{tabular}{l|c|c|c|c|c|c}
\hline \multirow{2}{*}{ Gender } & \multicolumn{2}{|c|}{ MA } & \multicolumn{2}{c|}{ PhD } & \multicolumn{2}{c}{ Specialty in Medicine } \\
\cline { 2 - 7 } & $\mathbf{f}$ & $\mathbf{\%}$ & $\mathbf{f}$ & $\mathbf{\%}$ & \multicolumn{1}{c}{$\mathbf{f}$} & \% \\
\hline Female & 13 & 68,42 & 4 & 80 & 1 & 100 \\
\hline Male & 6 & 31,57 & 1 & 20 & - & - \\
\hline Total & 19 & 100 & 5 & 100 & 1 & 100 \\
\hline
\end{tabular}

As seen in Table $3,68,42 \%$ of the MA theses were written by females and $31,57 \%$ by males. $80 \%$ of the PhD theses were prepared by females and $20 \%$ by males. It was found that all $(100 \%)$ of the study of specialty in medicine was written by a female researcher.

Table-4. Distribution of graduate theses in different disciplines prepared for music education in turkey regarding the publication year.

\begin{tabular}{|c|c|c|c|c|c|c|}
\hline \multirow[b]{2}{*}{ Publication Year } & \multicolumn{2}{|c|}{ MA } & \multicolumn{2}{|c|}{$\mathrm{PhD}$} & \multicolumn{2}{|c|}{ Speciality in Medicine } \\
\hline & $\mathrm{f}$ & $\%$ & $\mathbf{f}$ & $\%$ & $\mathbf{f}$ & $\%$ \\
\hline 1995 & 1 & 5,263 & - & - & - & - \\
\hline 1997 & - & - & 1 & 20 & - & - \\
\hline 1998 & 1 & 5,263 & - & - & - & - \\
\hline 2000 & 1 & 5,263 & - & - & - & - \\
\hline 2002 & 2 & 10,526 & 1 & 20 & - & - \\
\hline 2005 & 1 & 5,263 & - & - & - & - \\
\hline 2007 & 1 & 5,263 & - & - & - & - \\
\hline 2008 & 2 & 10,526 & - & - & - & - \\
\hline 2009 & 1 & 5,263 & - & - & - & - \\
\hline 2011 & 1 & 5,263 & - & - & - & - \\
\hline 2012 & - & - & - & - & 1 & 100 \\
\hline 2013 & - & - & 1 & 20 & - & - \\
\hline 2014 & 2 & 10,526 & 1 & 20 & - & - \\
\hline 2015 & 1 & 5,263 & - & - & - & - \\
\hline 2016 & 2 & 10,526 & - & - & - & - \\
\hline 2017 & 1 & 5,263 & - & - & - & - \\
\hline 2019 & 2 & 10,526 & 1 & 20 & - & - \\
\hline Total & 19 & 100 & 5 & 100 & 1 & 100 \\
\hline
\end{tabular}

As seen in Table 4, 10,526\% of the MA theses were submitted in 2002,2008, 2014, 2016,2019 and 5,263\% in 1995, 1998, 2000, 2005, 2007, 2009, 2011, 2015, 2017. 20\% of the $\mathrm{PhD}$ theses were prepared in 1997, 2002, 2013, 2014 and 2019. The study of the speciality in medicine was prepared in 2012.

Table-5. Distribution of graduate theses in different disciplines prepared for music education in turkey regarding the advisor's title.

\begin{tabular}{l|c|c|c|c|c|c}
\hline \multirow{2}{*}{ Title of Advisor } & \multicolumn{3}{c}{ MA } & \multicolumn{2}{c}{ PhD } & \multicolumn{3}{c}{ Speciality in Medicine } \\
\cline { 2 - 7 } & f & \% & f & \% & f & \% \\
\hline Assistant Prof. & 6 & 31,57 & 1 & 20 & - & - \\
\hline Associate Prof. & 5 & 26,31 & - & - & 1 & 100 \\
\hline Professor & 8 & 42,10 & 4 & 80 & - & - \\
\hline Total & 19 & 100 & 5 & 100 & 1 & 100 \\
\hline
\end{tabular}

As seen in Table 5, 42.10\% of the MA theses were supervised by professors; $31.57 \%$ by assistant professor and $26.31 \%$ of them by associate professor. $80 \%$ of the $\mathrm{PhD}$ theses were carried out under the consultancy of the professors and $20 \%$ were by associate/assistant professors. The study in specialty in medicine (100\%) was prepared under the supervision of an associate professor.

Table-6. Distribution of graduate theses in different disciplines prepared for music education in turkey regarding the institutes.

\begin{tabular}{l|c|c|c|c|c|c}
\hline \multirow{2}{*}{ Institute } & \multicolumn{2}{|c|}{ MA } & \multicolumn{2}{c}{ PhD } & \multicolumn{2}{c}{ Speciality in Medicine } \\
\cline { 2 - 7 } & f & \% & f & \% & f & \% \\
\hline Institute of Educational Sciences & 7 & 36,84 & 2 & 40 & - & - \\
\hline Institute of Social Sciences & 4 & 21,05 & 1 & 20 & - & - \\
\hline Institute of Health Sciences & 8 & 42,10 & - & - & - & - \\
\hline Institute of Science & - & - & 2 & 40 & - & - \\
\hline Medical School & - & - & - & - & 1 & 100 \\
\hline Total & 19 & 100 & 5 & 100 & 1 & 100 \\
\hline
\end{tabular}

As can be seen in Table 6, 42.10\% of the MA theses were prepared in the Institute of Health Sciences, 36.84\% of the Institute of Educational Sciences and $21.05 \%$ of the Institute of Social Sciences. $40 \%$ of the PhD theses were prepared in the Institute of Educational Sciences, and 20\% in the Institute of Social Sciences. The study in specialty in medicine in was prepared in the Faculty of Medicine. 


\begin{tabular}{|c|c|c|c|c|c|c|}
\hline \multirow[t]{2}{*}{ Department/Program } & \multicolumn{2}{|c|}{ MA } & \multicolumn{2}{|c|}{ PhD } & \multicolumn{2}{|c|}{ Speciality in Medicine } \\
\hline & $\mathbf{f}$ & $\%$ & $\mathbf{f}$ & $\%$ & f & $\%$ \\
\hline $\begin{array}{l}\text { Department of Educational Administration and Policy } \\
\text { department/ Education Management and Inspection } \\
\text { Program }\end{array}$ & 1 & 5,263 & - & - & - & - \\
\hline $\begin{array}{l}\text { Department of Educational Sciences/ Social and } \\
\text { Historical Fundamentals of Education/ } \\
\text { Cultural Foundations of Education }\end{array}$ & 1 & 5,263 & 1 & 20 & - & - \\
\hline Department of Education Programs and Teaching & 1 & 5,263 & - & - & - & - \\
\hline Department of Preschool Education & 2 & 10,526 & - & - & - & - \\
\hline $\begin{array}{l}\text { Home Economics (Child } \\
\text { Development and Education }\end{array}$ & 2 & 10,526 & 2 & 40 & - & - \\
\hline $\begin{array}{l}\text { Department of Primary Education/Primary School } \\
\text { Teaching }\end{array}$ & 2 & 10,526 & 1 & 20 & - & - \\
\hline Child Health and Education Program & 1 & 5,263 & - & - & - & - \\
\hline Department of Science Education & 1 & 5,263 & - & - & - & - \\
\hline $\begin{array}{l}\text { Department of Otorhinolaryngology and Head and } \\
\text { Neck Surgery }\end{array}$ & - & - & - & - & 1 & 100 \\
\hline Audiology and Speech Disorders Program & 3 & 15,789 & - & - & - & - \\
\hline Department of Orthopedics and Traumatology & 1 & 5,263 & - & - & - & - \\
\hline Department of Physical Therapy and Rehabilitation & 1 & 5,263 & - & - & - & - \\
\hline Department of Behavioral Sciences & 1 & 5,263 & - & - & - & - \\
\hline Department of Neuroscience & 1 & 5,263 & - & - & - & - \\
\hline $\begin{array}{l}\text { Department of Business Administration / Business } \\
\text { Management }\end{array}$ & 1 & 5,263 & - & - & - & - \\
\hline Department of Sociology & - & - & 1 & 20 & - & - \\
\hline Total & 19 & 100 & 5 & 100 & 1 & 100 \\
\hline
\end{tabular}

As can be seen in Table 7, 15,789\% of the MA theses were prepared in the Audiology and Speech Disorders Program; 10,526\% in the Department of Preschool Teaching / Education, in the Department of Home Economics (Child Development) / Child Development and Education, and in the Department of Primary Education / Primary School Teaching. 5,263\% of the MA theses were prepared in the Department of Educational Administration and Policy/Education Management and Inspection Program, in the Department Educational Sciences/Social and Historical Fundamentals of Education/ Cultural Foundations of Education, in the Department of Education Programs and Teaching, in the Child Health and Education Program, in the Department of Science Education, in the Department of Orthopedics and Traumatology, in the Department of Physical Therapy and Rehabilitation, in the Department of Behavioral Sciences, in the Department of Neuroscience and in the Department of Business Administration / Business Management.

$40 \%$ of the $\mathrm{PhD}$ theses were prepared in the Department Home Economics (Child Development)/Child Development and Education, and $20 \%$ in the Department of Educational Sciences/ Social and Historical Fundamentals of Education/Cultural Foundations of Education, in the Department of Primary Education/Primary School Teaching and in the department of Sociology. The study in the Department of Speciality in Medicine was prepared in the Department of Otorhinolaryngology and Head and Neck Surgery.

\begin{tabular}{|c|c|c|c|c|c|c|}
\hline \multirow[t]{2}{*}{ Research Area } & \multicolumn{2}{|c|}{ MA } & \multicolumn{2}{|c|}{ PhD } & \multicolumn{2}{|c|}{ Speciality in Medicine } \\
\hline & f & $\%$ & f & $\%$ & f & $\%$ \\
\hline Education Policies & 1 & 5,263 & 1 & 20 & - & - \\
\hline Education Materials/Materials Development & 1 & 5,263 & - & - & - & - \\
\hline Secondary Education Institutions & 1 & 5,263 & - & - & - & - \\
\hline Program Evaluation & 1 & 5,263 & - & - & - & - \\
\hline Preschool Education & 4 & 21,052 & 1 & 20 & - & - \\
\hline Mathematics Education & - & - & 1 & 20 & - & - \\
\hline Turkish & 1 & 5,263 & - & - & - & - \\
\hline Science Education & 1 & 5,263 & - & - & - & - \\
\hline Laryngeal Diseases & - & - & - & - & 1 & 100 \\
\hline Stuttering Treatment & 1 & 5,263 & - & - & - & - \\
\hline Orthopedics and Traumatology & 1 & 5,263 & - & - & - & - \\
\hline Frequency Sensitivity & 1 & 5,263 & - & - & - & - \\
\hline Pain Sensitivity & 1 & 5,263 & - & - & - & - \\
\hline Cognitive Function & 1 & 5,263 & - & - & - & - \\
\hline Hearing & 1 & 5,263 & - & - & - & - \\
\hline Language Development & 1 & 5,263 & - & - & - & - \\
\hline Time Perception & 1 & 5,263 & - & - & - & - \\
\hline Empathic Skills & - & - & 1 & 20 & - & - \\
\hline Sociology & - & - & 1 & 20 & - & - \\
\hline History & 1 & 5,263 & - & - & - & - \\
\hline Total & 19 & 100 & 5 & 100 & 1 & 100 \\
\hline
\end{tabular}

As seen in Table 8, 21,052\% of the MA theses were written in the field of Preschool Education and 5,263\% are in the Education Policies, Educational Materials/Material Development, Secondary Education Institutions, Program Evaluation, Turkish, Science Education, Stuttering Treatment, Orthopedics and Traumatology, 
Frequency Sensitivity, Pain Sensitivity, Cognitive Function, Hearing, Language Development, Time Perception and History.

$20 \%$ of the $\mathrm{PhD}$ theses were prepared for the fields of Education Policies, Preschool Education, Mathematics Education, Empathic Skills and Sociology. The study in specialtiy in medicine was defended in the field of Laryngeal Diseases.

Table-9. Distribution of graduate theses in different disciplines prepared for music education in turkey regarding the

\begin{tabular}{l|c|c|c|c|c|c}
\hline \multirow{2}{*}{ Research Model } & \multicolumn{2}{|c|}{ MA } & \multicolumn{2}{c|}{ PhD } & \multicolumn{2}{c}{ Speciality in Medicine } \\
\cline { 2 - 8 } & $\mathbf{f}$ & $\mathbf{\%}$ & $\mathbf{f}$ & $\mathbf{\%}$ & $\mathbf{f}$ & $\mathbf{\%}$ \\
\hline Descriptive Model & 13 & 68,42 & 3 & 60 & 1 & 100 \\
\hline Experimental Model & 6 & 31,57 & 1 & 20 & - & - \\
\hline Mixed Model & - & - & 1 & 20 & - & - \\
\hline Total & 19 & 100 & 5 & 100 & 1 & 100 \\
\hline
\end{tabular}

As seen in Table 9, $68.42 \%$ of the MA theses examined within the scope of the study were prepared based on the descriptive model and $31.57 \%$ on the experimental model. There is no study prepared based on the mixed model among the MA theses. $60 \%$ of the $\mathrm{PhD}$ theses were prepared based on the descriptive and $20 \%$ on the experimental and mixed model. It was determined that the study in specialty in medicine was prepared based on the descriptive model.

Table-10. Distribution of graduate theses in different disciplines prepared for music education in turkey regarding the research class.

\begin{tabular}{l|c|c|c|c|c|c}
\hline \multirow{2}{*}{ Research Class } & \multicolumn{2}{|c|}{ MA } & \multicolumn{2}{c|}{ PhD } & \multicolumn{2}{c}{ Speciality in Medicine } \\
\cline { 2 - 7 } & $\mathbf{f}$ & $\mathbf{\%}$ & $\mathbf{f}$ & $\mathbf{\%}$ & \multicolumn{1}{c}{$\mathbf{f}$} & $\mathbf{\%}$ \\
\hline Qualitative & 4 & 21,05 & 1 & 20 & - & - \\
\hline Quantitative & 15 & 78,94 & 4 & 80 & 1 & 100 \\
\hline Total & 19 & 100 & 5 & 100 & 1 & 100 \\
\hline
\end{tabular}

As seen in Table 10, 78.94\% of the MA theses examined within the scope of the study are quantitative research and 21.05 are qualitative research. $80 \%$ of $\mathrm{PhD}$ theses are in quantitative research and $20 \%$ are in qualitative research. The study in specialty in medicine within the scope of the research $(100 \%)$ was in the quantitative research class.

\section{Conclusion and Discussion}

1. It was found that the theses examined within the scope of the study were written between 1995 and 2019 , and that $76 \%$ of these theses consist of MA, $20 \% \mathrm{PhD}$ and $4 \%$ specialty in medicine theses. Ece and Ceşit (2011) point out that a large part of interdisciplinary music research is at MA thesis level, which is in line with the results of the current study. As of the 2019-2020 academic year, the total number of MA students is 297,001 while the number of PhD students is 101,242 (Higher Education İnformation Management System, 2020). According to these data, the number of MA students is almost three times higher than the number of PhD students. It can be said that the high numbers in MA thesis studies results from this situation.

2. Most of the MA theses examined within the scope of the research were prepared in Hacettepe University and most of the PhD theses were in Ankara University and the study in specialty in medicine was completed in Gaziosmanpaşa University.

3. Most of the MA and PhD theses examined within the scope of the research were written by women, and the study in specialty in medicine was prepared by a female researcher. Kılıç (2010) states that women are more involved than men in graduate music education research, which is also in line with the result of this research. According to the data of YÖK statistics (Higher Education İnformation Management System, 2020) the number of female researchers who graduated from the areas (health, education, etc.) examined in this study is almost twice as high as male researchers. The reason for finding the high number of theses prepared by women in this study is thought to be related to this situation.

4. $10,526 \%$ of the MA theses examined within the scope of the study were written in 2002,2008, 2014, 2016,2019; 5,263\% were in 1995, 1998, 2000, 2005, 2007, 2009, 2011, 2015, 2017. 20\% of the PhD theses within the scope of the study were prepared in 1997, 2002, 2013, 2014 and 2019. The study in speciality in medicine within the scope of the study was prepared in 2012. Thus, it is possible to say that the number of graduate studies in different disciplines prepared for music education in Turkey is not so high and it follows a horizontal distribution. Turna and Bolat (2015) also state that as compared with other countries, the number of interdisciplinary studies in Turkey is rather limitted and especially the PhD studies are inadequate. It can be said that this situation may result from the insufficient knowledge about interdisciplinary studies and the lack of communication between the institutions. Likewise, researchers' lack of competence in the field of music can be counted among the reasons for this situation.

$5.42 .10 \%$ of the MA theses examined within the scope of the study were under the supervision of professors; $31.57 \%$ under the supervision of assistant professors and $26.31 \%$ under the supervision of associate professors. $80 \%$ of the $\mathrm{PhD}$ theses were supervised by professors and $20 \%$ by assistant professors or doctors. The study in specialty in medicine $(100 \%)$ was prepared under the supervision of an associate professor.

6. It was turned out that most of the MA theses examined within the scope of the study were prepared in the Institutes of Health Sciences and most of the PhD theses were prepared in the Institutions of Educational Sciences and the specialty in medicine was carried out in the Faculty of Medicine.

7. Most of the MA theses examined within the scope of the study were prepared in the Audiology and Speech Disorders Program. Most of the PhD theses were prepared in the Department of Home Economics (Child 
Development)/Child Development and Education. Lastly, the study in specialty in medicine was prepared in the Department of Otorhinolaryngology and Head and Neck Surgery.

8. Music education was associated with preschool education in most of the MA theses examined within the scope of the study. The reason for this can be that musical activities have an indispensable role in preschool education and that music education is used as a tool in teaching different fields. As a matter of fact, Özkut and Kaya (2012) point out that music has a very important place in art education, which is a dimension of preschool education. Thus, it is usual that there are much more interdisciplinary studies linking music education and preschool education.

The $\mathrm{PhD}$ theses examined within the scope of the study were equally distributed in the fields of Education Policies, Preschool Education, Mathematics Education, Empathic Skills and Sociology. In this context, the role of music in educational sciences, preschool education and in education of different fields, and the association of music education with fields such as psychology, sociology, history stand out at the PhD level research. Especially, the study of subjects as treatment of disease and music education, and the effects of music on diseases is interesting.

9. Most of the MA and PhD theses and the study in specialty in medicine examined within the scope of the study were prepared based on descriptive model and quantitative approach. Since most of the researchers try to reveal an existing situation by explaining it, it is possible to say that the descriptive model is preferred more. Similarly, it is concluded that quantitative approach is preferred in most of the theses, since it is objective and suitable for more sampling and generalization. In fact, Gürdal, Bakioğlu, and Öztuna (2005) express that a large number of subjects can be reached through quantitative studies and the results of such studies are generalizable.

\section{Suggestions}

1. Primary issues in interdisciplinary studies on music education can be determined and researchers who work on these issues can be encouraged by providing scholarships.

2. Not only academics competent in the field of music but also those in different fields such as engineering, medicine, health sciences, etc. can be employed in the research centers for music and music education, and new thesis under the supervision of these academics can be prepared.

3. The number of graduate studies on educational sciences, preschool education, the role of music education in education of different fields, and on the association of music education with psychology, sociology, history can be increased.

4. Among the graduate studies associated with music education, the number of studies prepared based on the experimental or mixed model can be increased

5. The number of qualitative research can be increased among the graduate studies associated with music education.

\section{References}

Alyörük, G. (2016). Graduate thesis in field of guitar performed in Turkey: A bibliography study. Ballkesir University The Journal of Social Sciences Institute, 35(19), 55-79.

Ece, A. S. (2007). Music related articles published in scientific journals (Bibliography)(2000-2006). Abant Izzet Baysal University Journal of Social Sciences, 15(2), 45-81.

Ece., A. S., \& Ceşit, C. (2011). The interdisciplinary music researches done at graduate level in Turkey and their results. The Journal of International Social Research, $17(4), 599-617$.

Ercan, H., \& Yıldırım, O. Ş. (2016). Analysis of music conferences held in Turkey: MUZED silk road conferences sample. Fine Arts, 11(4), $181-199$.

Gürdal, A., Bakioğlu, A., \& Öztuna, A. (2005). Examination of science education graduate Theses. Buca Faculty of Education Journal, 17 (Special Issue 1), 53-58.

Higher Education İnformation Management System. (2020). Retrieved from https://istatistik.yok.gov.tr/.

Kılıç, I. (2010). The examination of graduate theses in music education. Paper presented at the 9. National Music Education Symposium, 15-17 December, İstanbul.

National Thesis Center. (2020). Retrieved from https://tez.yok.gov.tr/UlusalTezMerkezi/.

Özkut, B., \& Kaya, Ö., S. (2012). An investigation into the effects of undergraduate music education of preschool teachers in elementary schools on their professional lives. International Journal of New Trends in Arts, Sports \& Science Education, 1(1), 167-179.

Turna, Ö., \& Bolat, M. (2015). An analysis of theses related to interdisciplinary approach in education. Ondokuz Mayis University Journal of Faculty of Education, 34(1), 35-55.

Varış, Y. A. (2012). The analysis of postgraduate dissertations on viola written in Turkey. The Journal of Academic Social Science Studies, 5(8), $1247-1260$.

Yıldırım, A., \& Şimşek, H. (2013). Qualitative research methods in the social sciences. Ankara: Seçkin Publications. 